\title{
Opinie
}

\section{Rozmowy z pisarką/pisarzem - nowa odsłona?}

Anna Łebkowska

TEKSTY DRUGIE 2019, NR 1, S. 368-383

DOI: 10.18318/td.2019.1.25 | ORCID: 0000-0002-3954-5388

$\mathbf{M}$ ożna by sądzić, że - w efekcie zapanowania ery Internetu i nowych form obecności w mediach społecznościowych - pewne tradycyjne gatunki literackie, a zwłaszcza te o wyraźnym aspekcie autobiograficznym, w sposób nieuchronny odejdą w zapomnienie. Takim właśnie zapadaniem w niepamięć mogłyby być zagrożone w szczególności dotychczasowe sposoby opisywania własnej, a także cudzej biografii, które zastąpione zostają współczesnymi odmianami internetowej konfesji i - ogólnie: życiem literackim wiedzionym w sieci'. Przecież ogromna - i nigdy dość podkreślania: nie do przecenienia - obfitość możliwości oferowanych przez świat Internetu: blogi, profile, strony, fora czytelnicze itd., stanowi w tej chwili wartość właściwie bezkonkurencyjną. Zajmowałam się swego czasu gatunkiem „rozmowy

1 Nawiązuję do tytułu ważnej książki Macieja Maryla Życie literackie w sieci. Pisarze, instytucje i odbiorcy wobec przemian technologicznych, Wydawnictwo IBL, Warszawa 2015.

\footnotetext{
Anna Łebkowska

- prof. dr hab. na

Wydziale Polonistyki

UJ. Główne kierunki

badań: literatura

w perspektywie

antropologii kul-

turowej, teorie płci

kulturowej, kategorie

narracji, empatia

jako antropologiczna

kategoria literatury,

cielesność, afekty,

zmysły; współczesne teorie fikcji literackiej; teorie możliwych światów, literatura XX i XXI wieku. Autorka książek: Fikcja jako możliwość (wyd. 2, Kraków 1998); Między teoriami a fikcją literacką (Kraków 2001); Empatia. O literackich narracjach przełomu XX i XXI wieku (Kraków 2008). Redaktor naczelna "Ruchu Literackiego".
} 
z pisarzem" ${ }^{2}$ i po latach zaczynałam się zastanawiać, czy nowe, proponowane przez Internet możliwości - w swoim niedającym się zaprzeczyć bogactwie i atrakcyjności - nie przyćmią tej postaci gatunkowej3. Tymczasem wszystko na to wskazuje, że dzieje się dokładnie odwrotnie. Tu krótkie wyjaśnienie: używam terminu „rozmowy z pisarzem” dla takiej sytuacji, gdy (najczęściej) mamy do czynienia $\mathrm{z}$ dwoma interlokutorami i jednym z nich jest właśnie pisarz, powstały tom jest zaś efektem konkretnego zamierzenia. Innymi słowy, nie interesują mnie - na przykład - skompletowane wywiady z różnych okresów, przeprowadzane z różnymi osobami ${ }^{4}$.

Przede wszystkim: wprawdzie w nieco mniejszym nasileniu niż jeszcze w latach 90., książki rozmowy-rzeki wciąż się ukazywały (zresztą - jak zwykle - nie tylko z pisarzami, ograniczam się jednak wyłącznie do tej formy). W 1997 roku wydane zostały rozmowy Włodzimierza Boleckiego z Gustawem Herlingiem-Grudzińskim Rozmowy w Dragonei. Publikowane są wznowienia, a także - by tak rzecz ujacć - rozmowy wielokrotne: mianowicie przeprowadzane przez różnych rozmówców z tym samym autorem. Zaczęło się - jak wiadomo - od rozmów z Miłoszem. Na pierwsze miejsce wysunął się jednak Tadeusz Konwicki jako interlokutor najwytrwalszy. Nagrano z nim i spisano aż trzy książki. Oprócz wydanego jeszcze w 1986 (I wyd.) Pół wieku czyśćca, gdzie prowadzącym rozmowę był Stanisław Nowicki, czyli Stanisław Bereś, w 2001 roku ukazał się tom Pamiętam, że było goraco (rozmawiają Katarzyna Bielas

2 A. Łebkowska Rozmowa z pisarzem. Analiza gatunku, w: Kryzys czy przełom. Studia z teorii i historii literatury, red. M. Lubelska, A. Łebkowska, Universitas, Kraków 1994. Później opublikowano następujące książki: K. Maciąg W kręgu problematyki „Pamiętników mówionych", Wyd. Wyższej Szkoły Pedagogicznej w Rzeszowie, Rzeszów 2001; A. Główczewski Poetyka i pragmatyka „rozmów z...", Wyd. Adam Marszałek, Toruń 2005. Warto sięgnąć do książki M. Szajnert Intencja Autora i interpretacja - między inwencja a atencją. Teksty i parateksty, Wyd. Uniwersytetu Łódzkiego, Łódź 2011.

3 Najdalej w funeralnej prognozie, a nawet w - jak się okazuje nietrafionym - przypieczętowaniu przewidywanego stanu rzeczy posunął się Dominik Antonik, który twierdzi w swojej książce „Kiedyś zainteresowanie autorem wyrażało się w obecności takich gatunków, jak rozmowy z pisarzem, książka mówiona czy ankieta. Dziś to już gatunki historyczne, bowiem zarówno chęć pisarzy do zdradzania swoich opinii i informacji o sobie, jak i ciekawość czytelników [...] znajdują ujście w intensywniejszych, bardziej bezpośrednich, pojemnych i łatwiej dostępnych kanałach informacyjnych". D. Antonik Autor jako marka. Literatura w kulturze audiowizualnej społeczeństwa informacyjnego, Kraków 2014, s. 41-42. Rzeczywistość okazała się - przynajmniej w tej chwili - zupełnie inna.

4 Odsyłam tu do artykułu A. Łebkowska Rozmowa z pisarzem..., w którym poruszam m.in. kwestię specyficznej sytuacji rozmów Gombrowicza. 
i Jacek Szczerba) i wreszcie już w 2011 roku tom W pośpiechu - rozmowę prowadzi Przemystaw Kaniecki (Wołowiec 2011) ${ }^{5}$.

Istotne miejsce w tej konkurencji przypada Stanisławowi Lemowi. Otóż prócz rozmów wydanych w 1987 roku, przeprowadzonych przez Stanisława Beresia, ukazała się w 2000 roku książka Świat na krawędzi. Ze Stanisławem Lemem rozmawia Tomasz Fiałkowski. Fiałkowski od razu we wstępie zaznacza odmienny od poprzedniego tomu charakter rozmów, wydanych po prawie 20 latach, w innej scenerii politycznej. Na marginesie: pozostali interlokutorzy nie mają zwyczaju odwoływać się do rozmów wcześniejszych, co w końcu nie dziwi, „rozmowy” niejako z założenia nie stanowią formuły zamkniętej i jednorazowej. Na tej podstawie można by skonstatować, że gatunek „rozmów z pisarzem w dekadach przełomu wieków jeszcze się trzymał, jeszcze trwał, choć rzeczywiście raczej na zasadzie pewnego wyciszenia niż rozkwitu.

Sytuacja zmienia się dosyć zaskakująco w ciągu ostatnich lat. Ukazują się bowiem jedna za drugą następujące książki: w roku 2013 nakładem Wydawnictwa Literackiego: Dorota Masłowska Dusza światowa. Rozmawia Agnieszka Drotkiewicz $^{6}$, w 2015 Życie to jednak strata jest. Andrzej Stasiuk w rozmowach z Dorotą Wodecką (w jednym roku od razu dwa wydania, w tym drugie rozszerzone o cały rozdział); w 2016 Zawsze nie ma nigdy. Jerzy Pilch w rozmowach z Eweliną Pietrowiak i w 2017 Inne ochoty. Jerzy Pilch w rozmowach z Eweliną Pietrowiak część 2 i wreszcie też w 2017 obszerny tom zatytułowany Jaka piękna iluzja. Magdalena Tulli w rozmowie z Justyną Dąbrowską?.

Wyjaśnienie, że znaczący wysyp tego właśnie gatunku jest jedynie kwestią przypadku, nie wydaje się wystarczające. Z kolei próba doszukiwania się swego rodzaju konkurencji między słowem drukowanym a mediami społecznościowymi też nie przekonuje. Jak sądzę, można upatrywać przyczyn powracającej fali rozmów-rzek we wciąż niegasnącej atrakcyjności form autobiograficznych w ogólności. Współczesne życie w sieci nie przyczynia się do wygaśnięcia bardziej tradycyjnych postaci gatunkowych, a wręcz przeciwnie,

5 Ukazały się też rozmowy St. Beresia z A. Sapkowskim: Historia i fantastyka, Warszawa 2005.

6 D. Masłowska Dusza światowa, rozmawia A. Drotkiewicz, Kraków 2013, od tej chwili cytaty w nawiasach z tego wydania.

7 Należy tu wymienić inne jeszcze pozycje: M. Głowiński, G. Wołowiec Czas nieprzewidziany. Rozmowa-rzeka, Warszawa 2018. Michał Głowiński w rozmowach koncentruje się raczej na aspekcie naukowym swojej biografii. Wszystko będzie inaczej. Z Haliną Bortnowską rozmawia Jolanta Steciuk, Kraków 2010, i in. 
niekiedy - na nowo je ożywia. Żywioł autobiograficzny jest na tyle mocny, że dawne gatunki nie zamierają, nie tylko trzymają się dosyć mocno, ale nabierają nowych barw.

Gdy w latach 90. pisałam o „rozmowach”, nie istniał w ramach tego gatunku problem pisarza/pisarki i to nie dlatego, że gramatyczne kwestie genderowe pojawiły się w polskim literaturoznawstwie nieco (choć już niewiele) później, ale raczej ze względu na nieobecność rozmów z autorkami na ówczesnym polskim rynku wydawniczym ${ }^{8}$. Stąd też na użytek tego artykułu krótkie zbliżenie właśnie książek-rozmów z pisarkami. Mam zarazem świadomość, że zestawienie nazwisk Masłowskiej i Tulli jest karkołomne, trudno przecież o bardziej odmienne od siebie twórczynie. Jedynie wspólnota gatunkowa może stanowić usprawiedliwienie, zwłaszcza że każda z autorek ucieka przed zamknięciem w stereotypowej formule literatury kobiecej.

\section{$* * *$}

W ramach grupy najnowszych książek-rozmów charakter najmocniej wykraczający poza dotychczasową tradycję przypisać należy Duszy światowej. Przede wszystkim obydwie rozmówczynie są, jak na ten gatunek, bardzo młode, a przywykliśmy przecież do rozmów z takimi pisarzami, którzy są co najmniej w sile wieku. Ponadto dialog prowadzą ze sobą przedstawicielki tego samego pokolenia (Masłowska 1983, Drotkiewicz 1981), w dodatku obydwie są pisarkami, co jeszcze samo w sobie nie byłoby niczym szczególnie nowym, wszak rozmowy pisarzy były już publikowane. Przypomnę tu tom Ocalony na wschodzie, w którym Piotr Szewc przeprowadza rozmowę z Julianem Stryjkowskim, różnica wieku była tu wyraźna; z kolei w rozmowach tej rangi co Mój wiek również - jak wiadomo - rozmawiają pisarze. Dzieli ich jedenaście lat. Natomiast bohaterki Duszy światowej są niemal rówieśnicami.

Następna zmiana: we wcześniejszych książkach zadający pytania starał się minimalizować swoją obecność i raczej wyciszyć swoje „ja”. Tymczasem

8 Na wszelki wypadek dodaję: tom Rozmowy z Mariq Kuncewiczowa, wyb., oprac. i posł. H. Zaworska, Warszawa 1983, ma jednak inny charakter, jest to bowiem zbiór różnych wywiadów przeprowadzanych z pisarką przez wiele osób, dla wielu czasopism, w ciągu kilkudziesięciu lat, nie mieści się zatem w przyjętej tu formule. Pomijam stan rzeczy w świecie, pomijam też fakt, że kobiety często stoją po stronie przeprowadzających rozmowy.

9 Miłosz w rozmowie z Watem mówi wprost: „Służę jako medium na tym dziwnym seansie Mój wiek", Wyd. Polonia Book Fund Ltd., Londyn 1977, s. 16. 
w Duszy światowej role wprawdzie są wyznaczone i dominują wypowiedzi Masłowskiej ${ }^{10}$, jednak ważny okazuje się sam sposób prowadzenia rozmowy: jeśli dawniej, przy wszystkich oczywistych zróżnicowaniach i niuansach, relacja między rozmawiającymi przypominała w sposób zdecydowany dialog biografa/biografki z autobiografem/autobiografką, tak w przypadku spotkań Agnieszki Drotkiewicz z Dorotą Masłowską dialog prowadzony jest często na zasadzie wymiany podobnych opinii na temat zjawisk współczesnego świata. Sytuacja ta zostaje podsunięta czytelnikowi wprost, na ostatniej stronie okładki zamieszczono bowiem takie oto słowa: Spotkanie: dwie kobiety, dwie pisarki, jedno pokolenie, ta sama dusza światowa.

Natomiast bez zmian pozostaje wysoka samoświadomość gatunkowa - cecha właściwie wszystkich dotychczasowych „rozmów”. W Duszy... uwidocznia się m.in. w niechęci do zaprogramowanych antagonizmów, nie tylko do tych służących podtrzymaniu napięcia, które były zresztą częstą cechą wcześniejszych rozmów, ale też do zaprogramowanych sporów podporządkowanych celom komercyjnym, a przypominających tabloidowe rewelacje. Tym samym, tworząc rozmowę, autorki jednocześnie omawiają jej niechcianą wersję. Nie sposób nie zauważyć demonstrowanej niechęci do wszelkich form świata celebryckiego.

Kolejna zmiana: zminimalizowane zostało nakierowanie na przeszłość i to w kilku aspektach, m.in. w tak zasadniczym jak oprowadzanie po własnej biografii. Deklarację odejścia od opowieści o dotychczasowym życiu znajdziemy tu kilkakrotnie, w szczególności w rozdziale Techniki wywiadu i wspomnienia. Oto znamienne słowa: Drotkiewicz: „pomyślałam o tym, że warto byłoby skomentować jakoś naszą technikę rozmowy, nasze podejście do tematu. Wyobrażam sobie, że sięgając po tę książkę, widząc, że to rozmowa - czytelnik może pomyśleć, że będą tu twoje wspomnienia w formie: «Dorota Masłowska opowiada o trudnym dzieciństwie, burzliwej młodości, zagranicznych podróżach i piciu szampana z pępka Maria Vargasa Llosy oraz Baracka Obamy»"11 i sama Masłowska - już w tonacji bardziej serio: "I w ogóle nie lubię opowiadać o rzeczach ze swojego życia” (127), „Nie lubię wspomnień. To co było, rozpadło się, przeminęło, zniknęło" (129).

Obydwie rozmówczynie zwracają uwagę na sam sposób budowania osobistej narracji i tym samym na niebezpieczną dostosowalność takiego życiorysu do

10 Co poświadcza kompozycja okładki, na pierwszej stronie fotografia samej Masłowskej, na ostatniej - obydwie pisarki, lecz Drotkiewicz jednak nieco z tyłu.

11 Dusza światowa, s. 126 
wymagań odbiorców, a stąd blisko do następnego zagrożenia, jakim byłoby - wspomniane już - podobieństwo do biografii celebryckich, które zasypują ostatnio rynek czytelniczy. Odrzucają też - dające się zauważyć w upodobaniach do kształtowania i ujawniania własnej biografii - skłonności do przekuwania w atrakcyjną opowieść nie tylko własnych sukcesów (co w końcu oczywiste), ale też i porażek ${ }^{12}$. Te ostatnie - ujawnione przez Masłowską w krótkim mgnieniu - natychmiast pokryte zostają milczeniem. W tle nieustanna awersja do narcystycznej autoafirmacji ironicznie określonej tak oto: „upajaj się sobą, nie musisz być ani odważna, ani mądra, ani dobra, ani żadna, wystarczy, że kochasz samą siebie" (79).

Mimo deklarowanej niechęci elementy przeszłości, wspomnień z minionego dzieciństwa i wczesnej młodości nie zostają całkowicie wyeliminowane. Pojawiają się na zasadzie luźnych wrażeń i powtarzalnych chwil. Wyraźny jest tu bowiem brak zgody na opowieść jednolitą, mocną, dookreśloną, zaznacza się natomiast predylekcja do narracji rozproszonej. Nie są to jednak wyłącznie śladowe sygnały przeszłości. Niektóre z przypomnianych zdarzeń opisywane są jako fundamentalne; „Do dziewiętnastego roku życia mieszkałam niedaleko morza: przez całe dzieciństwo wszystkie letnie miesiące przesiadywałam nad morzem i myślę, że moja z nim relacja jest czymś innym niż metafizyczny zachwyt jego ogromem. Dla mnie jego widok, zapach są czymś silnie związanym z jądrem mojej osoby, są takim motywem podprogowym, pierwocinami mnie [...] wiem, pamiętam, jak stałam tak na tej plaży w osiemdziesiątym piątym, osiemdziesiątym szóstym - każdego roku - przez całe moje życie przewija się sytuacja stania w lodowatej wodzie, pod szarym niebem, wobec tej nieskończoności. Na horyzoncie majaczy jakiś krzywy statek, melancholijna plaża z białym piaskiem i wypłukanymi słoną wodą drzewami. To jest moja konstytucja" (9/10). Niewątpliwie sam akt doświadczania świata - także w swojej iteratywności - staje się tu najważniejszy, ma moc konstytuowania podmiotu i jako taki poddawany zostaje ex post autointerpretacji.

Drugą „, chwilę istnienia” - używając określenia Virginii Woolf - znajdziemy we fragmencie rozmowy z rozdziału Przyroda i ciało, w którym dwie pisarki rozmawiają o przyjemności wynikającej z kontaktu z ziemią: (Masłowska) „Babrząc się w błocie, nagle poczułam się z powrotem żywa (178). Wkładasz

Prosi się w tym miejscu uwaga, że lubowanie się we własnych wspomnieniach (tak obce Masłowskiej), kształtowanie z nich pewnej opowieści i odnajdywanie w tym przyjemności częściej przychodzi z wiekiem (choć oczywiście nie ma tu reguł...). 
ręce w planetę, dotykasz jej [...] to wszystko tętni, to jest życie, z którym nie mamy kontaktu” (181). Zależność między tym, co wstrętne („bliskość robaków, dżdżownic, much, szczypawek" (181) a endorfinami, jak się okazuje - wydzielanymi w czasie kontaktu z ziemią, to jeden z powodów fascynacji naturą.

Nie wyławiam tych akurat fragmentów po to, żeby przykleić etykietę np. ekofeminizmu i zamknąć temat. Interesuje mnie co innego, mianowicie problem doświadczania świata i bezpośredniego, wprost tematyzowanego, z nim kontaktu. Otóż owo „zanurzenie się w przyrodę” (11) kontrastuje z tytułową „duszą światową". W przypadku natury chodziło o niezapośredniczony dotyk, stwarzający od nowa, o witalną siłę dającą moc itd., natomiast dusza światowa ujmowana jest w sposób co najmniej ambiwalentny. Nie chodzi tu bowiem o bezpośredni kontakt, ale o swoistą interakcję międzyludzką, która w dodatku staje się osią całej rozmowy i zarazem jej ramą kompozycyjną. Książkę otwiera motto: cytat z Mewy Czechowa ukazujący znamienną dla epoki dramaturga tęsknotę do komunii dusz, także dusz zmarłych, które „zlały się w jedną", i oznacza też marzenie o stopieniu się z tłumem np. ulicznym, co w najlepszej postaci miałaby oferować nadmorska (!) Genua. Istotę "duszy” można, przykładając tonację serio, zamknąć w tęsknocie za pojęciami doby wysokiego modernizmu (np. sztuka zrównana z religią, 106); jednocześnie jednak - dobrze wiadomo - nie o istotę tu chodzi ani też nie o idealizację, a raczej o płynność i mobilność używanych pojęć, ich niejasność, ale też niepokój, który mogą budzić. Sfera Internetu: mediów społecznościowych w swojej sile hejtu, anonimowych pogróżek i nieusuwalnej, a zarazem wzbudzającej lęk trwałości i nieusuwalności zostaje tu ukazana właśnie jako współczesna wersja duszy światowej.

Jednocześnie współgrająca z tą sferą zasada uczestniczenia, która wyjątkowo często pojawia się w rozmowach, nie jest tożsama ze ścisłą wspólnotą, z przynależnością, ma raczej przypominać działania antropolożek codzienności - jak autorki same się określają (175). Ma być czymś w rodzaju przygody socjologicznej, opartej na niestandardowych interakcjach (192) poszerzaniu poczucia świata (211), tworzącej jednocześnie wagary niedorzeczności (193). Tak pojmowane interakcje połączone z wchodzeniem w cudze życie, zawierać muszą w sobie element absurdu, mają być zderzeniem uważności z tym, co niedorzeczne. Nie dziwi zatem zdanie wypowiedziane przez Masłowską: „Mam bardzo niskie poczucie bycia częścią duszy światowej" (230).

Oczywiście sytuację tę najłatwiej spointować krótkim stwierdzeniem, że po prostu całą książkę utrzymano w konwencji niezobowiązującej, luźniej 
rozmowy. Nie podlega też kwestii, że obydwie rozmówczynie mają świadomość gry banałem ${ }^{13}$, ale jednocześnie - niekiedy przynajmniej - pokrywania właśnie banałem skrywanego niepokoju, lęku przed zniewoleniem i niechcianą przynależnością, zarazem także przed przesadną wolnością: przed byciem miluchem i przed ludźmi źle wolnymi iźle sytymi (112). Sfera niepokojów, doznań, stanów emocjonalnych jest tu przesłonięta przedrzeźnianiem, kpiną, które niosą w sobie wyraźną moc interwencyjną.

Rozmowy oparte są na wspólnym obu autorkom poczuciu humoru i na niechęci do sądów radykalnych czy jakichkolwiek doktryn. Masłowska nieustannie dokonuje rewizji własnych poglądów, osłabia moc przedstawianych chwilę wcześniej opinii. Przykładowo, opisując własną niechęć do wspomnień i do archiwizowania pamiątek (także zdjęć), dodaje, że oglądane u innych jednak robia wrażenie (130); wspomina własne rozterki i wyrzuty sumienia po napisaniu emocjonalnej recenzji, deklaruje niechęć do wspomnień, a jednak sięga do przeszłości. Nie tylko dystansuje się wobec narcystycznej fascynacji ciałem, ale jednocześnie stwierdza: „Moje ciało jest w zasadzie ciałem obcym, traktuję je jako narośl, coś co umożliwia mi przemieszczanie mózgu" (186) i w innym miejscu - też o ciele: „ja tym nie zawiaduję”, by zaraz, jakby na przekór, dodać: „Muszę biegać, chodzić albo jeździć na rowerze - wtedy słucham muzyki, i to jest jedna z moich większych przyjemności w życiu" (187) itd. Owo osłabienie własnych sądów widać zwłaszcza w części ostatniej, zatytułowanej Później, zdominowanej przez niepokój wynikający z natychmiastowej dezaktualizacji opisanego w rozmowach świata. Otóż Masłowska w swojej awersji do pryncypialności wycofuje się z jednoznacznej krytyki Facebooka, wyjaśniając, że jako osobie wyjątkowo intensywnie pojawiającej się w mediach łatwiej jest wyzwolić się z widocznego u innych kompulsywnego wręcz pragnienia tego typu obecności. Osłabianie i korygowanie własnych sądów nie oznacza wewnętrznej sprzeczności, polega raczej na szukaniu przeciwwagi, na niechęci do przesadnie autorytarnych wypowiedzi, na docenianiu rozmowy. Jeden z postulatów Duszy wypowiadany

13 Książka ta spotkała się z nie najlepszymi ocenami. Atakowano ją właśne za nadmiar banałów i infantylnych uwag o świecie. Zarzuty tego rodzaju bodaj najdosadniej sformułował P. Bratkowski, jednopłaszczyznowo odczytując tę książkę i pisząc o rozczarowaniu, które mu przyniosła. Wśród innych zarzutów pojawił się także ten dotyczący wieku: pisano, że autorka jest za młoda na monumentalizujące własne „ja” działania, zakładając niejako, że rozmowa-rzeka zzałożenia jest stawianiem sobie pomników. Por. recenzje. Nie będę też ukrywać: inaczej czyta się Duszę światowa po paru latach, po ukazaniu się tomu znakomitych felietonów w tomie /ak przejąć kontrolę nad światem nie wychodząc z domu, aniżeli w chwili jej publikacji. 
na przekór Facebookowi brzmi: „trzeba inwestować w analogowe kontakty” (89). Rozmowa jest przecież tego postulatu spełnieniem

\section{*⿻⺀从火}

W roku 2017 ukazał się tom Jaka piękna iluzja. Magdalena Tulli w rozmowie z Justyną Dąbrowską ${ }^{14}$, w zasadzie skrajnie odmienny od Duszy światowej. „W zasadzie", gdyż pewne podobieństwa da się tu jednak wykazać (o czym za chwilę). Nie jest to spotkanie dwóch pisarek - być może właśnie dlatego - więcej tu interpretacji własnych utworów, więcej nawiązań do prozy Tulli. Każdy rozdział zaczyna się od cytatu z którejś z jej powieści. Role zostały rozdane w sposób bardziej klasyczny: Justyna Dąbrowska - mająca już w swoim dorobku wiele przeprowadzonych wywiadów - głównie zadaje pytania, ale też niekiedy sytuacja ulega odwróceniu: pisarka pyta swoją rozmówczynię. Z kolei pytania Dąbrowskiej krótkie, dociekliwe, zadawane z dużą częstotliwością, zarazem delikatne, świadczą o dobrym, bliskim wzajemnym kontakcie. Nie ma tu wprawdzie znamiennej dla Duszy światowej niechęci do przywoływania własnej przeszłości, jednak ujęcie czasów minionych jest bardzo odległe od tradycji gatunku.

Trudno nie czytać rozmów poprzez Włoskie szpilki i Szum - niejako wbrew samej autorce, która odżegnuje się od utożsamiania tych utworów z prostą autobiografią. Nie sposób jednak nie widzieć w każdym z tych tekstów przepracowywania wciąż tej samej traumy. Przeszłość jest konsekwentnie podsuwana jako rana dawno zagojona, jako zamknięta całość ułożona niczym puzzle: wszystkie elementy do siebie pasują i nie da się ich zestawić w inny sposób,jednak dobrze wiemy, że ta wyjaśniona układanka nie daje się całkowicie zepchnąć do czasów minionych, że przeszłe zdarzenia są wciąż - w dojmujący sposób obecne, choć na tyle już przesłonięte autoterapeutyczną interpretacją, że można o nich opowiadać. Z kolei sprawa uczestnictwa w świecie, dla obu pisarek istotna, u Masłowskiej nieoczywista, na różne sposoby oswajana, odrzucana, przedrzeźniana, u Tulli wiąże się przede wszystkim z odrzuceniem. Przedstawione aktywności w tym - rzecz jasna - zwłaszcza twórczość literacka, ale też np. śpiew w chórze (dający przecież i wspólnotę, i niezależność), wreszcie: co się samo nasuwa, właśnie rozmowa - stanowią też swoistą autoterapię. Trauma odrzucenia właściwie przez wszystkich, z którymi miała kontakt, poczucie nieprzynależności i wynikająca właśnie stąd niemożność przystosowania, kłopoty

14 Jaka piękna iluzja. Magdalena Tulli w rozmowie z Justyną Dąbrowską, Kraków 2017. 
rozwojowe w dzieciństwie, nieustanne lęki, dysleksja, dysgrafia, bezsenność, określiły całe jej dzieciństwo i młodość, były źródłem trudnych do zniesienia cierpień. Wielkoduszne względem rodziny, zwłaszcza matki, uporanie się z traumą własnego dzieciństwa nie pozostawia miejsca na dystans prześmiewczy czy autoironię, którą interlokutorzy większości rozmów szermują, przez cały czas budując nad sobą ochronny parasol. Natomiast proponowane przez Tulli inne wyjście literackie (i też swoista osłona) wypróbowywane we wcześniejszej twórczości, mianowicie przeniesienie całej niesłychanie trudnej sfery emocjonalno-afektywnej na obszar tekstów literackich na zasadzie ich przetransponowania na równie skomplikowaną, wieloznaczną i metatekstową kompozycję (chodzi o Tryby) - jak sama twierdzi - nie znalazło zrozumienia w oczach krytyki. Miejsce u innych wypełniane przez prześmiewczy autodystans tutaj zajmuje niepewność i wątpienie, ale też - niebudzący zdziwienia - brak ufności. Uważność dla drugiego człowieka jest sprawą zasadniczą i deklarowaną, choć nieoczywistą i trudną; (Dąbrowska): „Potrafisz wejść w skórę drugiego człowieka”, (Tulli): „Pewnie zawdzięczam to skłonności do wątpienia. To ona zachęca do przyjmowania różnych perspektyw, rozwija intuicję. Gdybym mogła sprawdzać swoje domysły, pewnie by się okazało, że nie wszystkie są trafione. Kiedy myślę o jakimś człowieku, z którym mam do czynienia, przede wszystkim zastanawiam się, jaka nas łączy relacja [...] Sprawdzam, czy jest symetryczna.Z niesymetrycznych relacji uciekam, na przykład z takich, w których strony nie są równie ważne" (67/68). Częste (a też i nowe dla gatunku rozmów z pisarzem) są tu pytania o emocje jak się tam czułaś? (59), a co ciebiew dzieciństwie najbardziej bolało (151); Jak sobie wtedy radziłaś ze smutkiem (153), jak myślisz, skad się biora zabezpieczenia, które powstrzymują gniew (160), całe rozdziały O smutku i gniewie, $O$ przemocy, $O$ miłości czy, metaforycznie: $O$ dźwiganiu ciężarów. W ramach ciągle obecnej - choć pozornie zamkniętej traumy biografii - pojawiają się też kwestie zachowań wobec dziecka, wychowania, delikatności, dawania swobody: Dąbrowska: „Pamiętałaś, jak to było być małą dziewczynką?” Tulli: "Pamiętałam, oczywiście. Więc miałam to na uwadze, żeby ich uczuć nie ranić" (27). Cały tom okalają ramy: początek o dzieciach, koniec o śmierci, tak jakby przebieg życia stanowił główny trzon rozmowy i tak jakby życie miało w sobie potencjał ocalający od traumy.

\section{*⿻*从一}

Jeśli dwie tak różniące się od siebie pisarki wybierają ten sam gatunek, trudno nie zadać pytania, czy pojawiają się tu jakieś wspólne cechy? 
Przede wszystkim każda autorka odżegnuje się od zatrzaśnięcia w schematach, w tym także - przypomnę - w stereotypach płci kulturowej. Masłowska uchyla się przed zatrzaśnięciem w literaturze kobiecej, ale tej popularnej, tożsamej z romansami, nie utożsamia się też z literaturą traktowaną (potocznie) jako męska. I to nie tylko pisaną dla szerokiego grona odbiorców, ale też np. autorstwa Ballarda czy Dukaja. Czyni to główne ze względu na nieodpowiadający jej brak bohaterek kobiecych i brak emocji. Stwierdza dobitnie: „diagnoza, że jako pisarka jestem obojnacza, jest dość trafna” (115) i jeszcze mocniej: „umysłowo od zawsze byłam obojnacza, mój mózg nie został zorientowany płciowo" (116). Nie zamierzam wytaczać teraz dział związanych z dyskusjami nad pojęciem „literatura kobieca”, chcę tylko podkreślić, że jeśli przyjmiemy tak uproszczone (a - jak się nam podsuwa - narzucone przez krytykę) jego rozumienie, wówczas trudno się z Masłowską nie zgodzić. Podobne konstatacje znajdziemy u Magdaleny Tulli, która - również niechętna wydzielaniu literatury kobiecej (i domykaniu jej twórczości w tym określeniu przez krytykę) nie bez pewnej irytacji wspomina znamienną dla lat 9o. skłonność do przypisania płci literaturze (84). Atakuje też ograniczenia wynikające z takiego podziału, stając zresztą po stronie kobiet („Dla kobiet ograniczenia są nie tylko inne niż dla mężczyzn, są przede wszystkim dużo dokładniej określone, oczekiwania bardziej szczegółowe i kategoryczne, zostawiają o wiele mniej przestrzeni" [84]), buntuje się przeciwko upraszczającemu zatrzaskiwaniu twórczości pisarek w schematach genderowych opartych na hybrydyczności, mieszaniu kwestii autorstwa, tematyki (kobieta bohaterką) i gatunków (romans). Nic dziwnego zatem, że pisarka twierdzi: „I nie wpasowałam się w potoczne wyobrażenia o tym, jak powinny pisać kobiety" (85). I znowu: trudno się z tym stanowiskiem nie zgodzić. Za każdym razem miejscem ataku jest nie tyle literatura pisana przez kobiety, ile krytyka literacka i publicystyka z jej ograniczeniami i przesadnie stereotypowym rozumieniem płci.

Z tych względów nie dziwi pozornie zaskakujący fakt, że - na przekór stereotypom - właśnie płeć - jak sądzę za zgodą autorek - została wyeksponowana na okładkach obydwu książek. Na ostatniej stronie rozmów z Masłowską: „Spotkanie: dwie kobiety. Dwie pisarki. Jedno pokolenie. Ta sama dusza światowa”. Z kolei u Tulli i Dąbrowskiej podobnie: „Dwie kobiety rozmawiają o tym, że może się tak zdarzyć, że jakaś część życia upłynie bez miłości. I o tym, że to nie niszczy doszczętnie [...] O równowadze, którą można pochwycić jak rzuconą z drugiego brzegu linę o mocnym splocie". Utożsamienie tego faktu wyłącznie z chwytem reklamowym byłoby uproszczeniem. 
Następne podobieństwo sprowadza się do wspomnianej już interlokucyjności opartej na porozumieniu o charakterze relacyjnym, widocznym albo w mówieniu jednym głosem, albo w obustronnym zadawaniu pytań i zarazem we wspólnej niechęci do antagonizmów: „Drotkiewicz: uderzyło mnie też, jak bardzo silne jest przekonanie, że wywiad to przesłuchanie, poligon, atak. Przeczytałam gdzieś zapowiedź naszej książki: «Ciekawe, czy Agnieszka przyprze Dorotę Masłowską do muru?»! I pomyślałam, że nasza rozmowa nie ma nic wspólnego z murem, z przypieraniem” i w Iluzji...: „Dąbrowska: przecież razem będziemy to redagowały, nie myślisz chyba, że ja tu poluję na ciebie. Tulli: Bardzo dobrze, nie poluj na mnie" (76/77). Obydwie pisarki skarżą się na niewłaściwe odczytanie przez krytykę literacką i publicystykę, szczególnie na pozbawione głębi przyklejanie banalnych etykietek: Masłowska w sensie polityczno-społecznym (córka Rydzyka), Tulli głównie w sensie krytycznoliterackim: (cyzelująca teksty i pisząca rebusy) ${ }^{15}$.U żadnej nie znajdziemy budowanej w trakcie rozmowy mocnej, scalonej narracji biograficznej: u Masłowskiej, jeśli w ogóle pojawiają się zwroty wstecz, to na zasadzie przywoływania momentów o szczególnej intensywności, u Tulli biografia traumatyczna omówiona w ramach nałożonej na nią rozwiązanej już zagadki, wciąż odsłania swój raniący charakter. Poniekąd wspólne jest też nakierowanie na drugiego człowieka, choć obrazowane w sposób skrajnie różny: jako wejście w cudza skórę (Dąbrowska/Tulli) i jako niestandardowe interakcje (Masłowska)

Nie sposób nie zadać też pytania o różnice w zestawieniu z pozostałymi książkami - rozmowami wydanymi ostatnio a przeprowadzanymi z pisarzami. Tu tylko kilka uwag. Otóż u Stasiuka i Pilcha pojawia się wyraźniejsza skłonność do uprawomocnienia własnej biografii, wskazania na linię rodzinną, miasto - miejsce pochodzenia, zakorzenienie, wyznanie decydujące o kształcie dzieciństwa. Biografie budowane są tak, żeby wskazać w nich momenty własnego wyboru i decyzji. Dla przykładu: etykiety są wymyślane i z premedytacją na siebie nakładane: wsiowy g tupek ${ }^{16}$ to wprawdzie też raczej określenie innych, ale jednak wybrane przez pisarza i z premedytacją dopasowane do siebie. U Masłowskiej rzecz wygląda jednak inaczej: większą widać tu zależność od kontekstów: pisarka w pewnym sensie dostosowuje się do opinii: dopiero po wydaniu Kotów i ukazaniu się różnych recenzji, w tym także

15 Skarga na niewłaściwe odczytanie i uchylanie się wszelkim kategoryzacjom to główne toposy tego gatunku.

16 A. Stasiuk Życie to jednak strata jest, Andrzej Stasiuk w rozmowach z Dorota Wodecką, CzarneAgora, Wołowiec, Warszawa 2015 s.88 
miażdżących (228), mógł nastąpić powrót do takich samookreśleń, które jej najbardziej odpowiadają: „Z powrotem trafiłam do mojego naturalnego stanu - stanu osoby krzywej, śmiesznej, niesformatowanej" (228).

stats

Pora na uogólnienia i odpowiedź na pytanie, czy rzeczywiście można mówić o nowej odsłonie rozmów?

Otóż w istocie, różnice są niekiedy wyraźne, co jednak nie oznacza braku ciągłości. Zacznę zatem od cech już znanych, ucukrzonych a jednocześnie wciąż trwających i aktualnych: wśród nich wyjątkowo mocno trzyma się samoobserwacja aktywności twórczych, zdawanie relacji z procesu pisania, z aktu twórczego. Nie zmieniły się działania autoprezentacyjne i zarazem autokreacyjne, choć dawniej były bardziej problematyzowane, nazywane wprost, ujawniane poprzez grę z rozmówcą. Można tu dodać, że poziom "meta", w tym poziom gatunkowej samoświadomości, nieco się nasilił, co należałoby tłumaczyć - między innymi - dłuższą jego historią, większą możliwością odwołań do istniejących już reguł. Jednakże wcześniej "rozmowy” utożsamiane były raczej z rozszerzeniem świata literackości, z redefinicją literatury, z nicowaniem granicy między fikcją a faktem. W tej chwili te problemy zeszły na dalszy plan. Nadal mamy do czynienia $\mathrm{z}$ odsłonięciem aspektu mówionego, z ujawnieniem sytuacji rozmowy, z kolei choć więcej jest teraz wspólnych działań, wspólnych podróży (np. Stasiuk jedzie samochodem ze swoją rozmówczynią). Aczkolwiek zdarzały się też wcześniej, np. w trakcie rozmowy z Konwickim: spacer do kawiarni. Pojawiają się te same co dawniej pytania np. dotyczące lektur i ich interpretacji, roli literatury...

Jakie zatem przesunięcia akcentów poświadczałyby zmianę?

Przede wszystkim dawniej wśród prowadzących dominowali badacze literatury, dzisiaj są to głównie rozmowy (spotkania...) twórców z twórcami. W mniejszym stopniu przyświeca tu zasada, by dowiedzieć się jak najwięcej o znaczeniu tekstów literackich, tym samym rzadsze są pytania o interpretacje utworów. Dawniej prowadzący rozmowę był animatorem zachęcającym do autointerpretacji, sygnalizującym zarazem nieustannie własną wiedzę o twórczości i przeszłości pisarza, obecnie jest to raczej współrozmówca: częściej są to rozmowy „ramię w ramię”, prowadzone - by tak się wyrazić - ze wspólnej pozycji, zazwyczaj w efekcie po prostu wspólnoty pokoleniowej. Stąd bierze się też inny rodzaj wzajemnej interakcji. Powtórzę: obydwie 
strony mogą zadawać pytania. Nawet w rozmowach z Jerzym Pilchem, które wpisują się w bardziej tradycyjną formułę, znajdziemy zdania: „nie będziemy gadać tylko o mnie. Właśnie wróciłaś ze swojego kolejnego europejskiego tygodnia” i dalej: „to nie ma być książka o mnie..."17. Choć nie ma tu oczywiście ścisłej symetrii, wiadomo, kto tak naprawdę pyta, a kto odpowiada. Relacja ta najbardziej zaciera się właśnie w Duszy światowej. I przyznać trzeba: spotkania kobiet-autorek (by użyć określenia z okładek) są jednak bardziej relacyjne, rozmowy z autorami - bardziej hierarchiczne. Gdy porównuje się ze sobą wydane współcześnie tomy, różnica okazuje się ewidentna.

Podobnie jak dawnymi laty, pisarze - interlokutorzy charakteryzują się - by tak rzecz ujacć - nachyleniem autobiograficznym: mają już w swoim dorobku dzienniki, autobiografie, a przynajmniej szeroko rozumiane postacie autobiografizmu (autobiograficzne felietony w przypadku Doroty Masłowskiej). Każdy z czwórki pisarzy jest zarazem mocno obecny w różnych formach komunikacji społecznej, mniej lub bardziej tradycyjnych. Można zatem przyjąć, że rozmowy są kolejną cegiełką dokładaną do medialnego wizerunku, stanowią rozszerzenie i tak już zazwyczaj rozległego pola obecności przeznaczonego dla odbiorców. Rzecz jasna, nasiliła się presja reklamy, promocji, z czego rozmówcy doskonale zdają sobie sprawę ${ }^{18}$, co zresztą - wbrew przewidywaniom - nie powoduje ich koniecznej obecności w internetowych mediach społecznościowych. Na przykład Tulli ma konto na Facebooku, natomiast Pilcha i Stasiuka próżno by tam szukać (nie mówię o stronach fanowskich). Masłowska, o czym już wiemy, jest programowo nieobecna na Facebooku. Niezależnie od stosunku do Facebooka, jak widać na tyle ważnego, że jako temat pojawia się w rozmowach, każdy z pisarzy wyjątkowo intensywnie zapewnia sobie obecność w mediach wszelakiego rodzaju ${ }^{19}$ i każdy ma wyraźne miejsce w świadomości społecznej.

W efekcie tych przemian współczesne rozmowy częściej nastawione są na teraźniejszość, zamiast kolejnych odcinków z przeszłości, zamiast jak

17 Zawsze nie ma nigdy. Jerzy Pilch w rozmowach z Eweliną Pietrowiak, Kraków 2016, s. 242.

18 Co w końcu oczywiste. Natomiast nie ma tu miejsca na rozwijanie wątku strategii i działań związanych ze świadomością tej sytuacji.

19

Obecność Masłowskiej w mediach świetnie opisał D. Antonik Dorota Masłowska: transmedialny projekt osobowościowy, w: Między sztukq̨ a codziennościq̨. W stronę nowej syntezy (1), red. M. Hopfinger, Z. Ziątek, T. Żukowski, Wydawnictwo IBL PAN, Warszawa 2016. Można tu też przypomnieć nagrania Stasiuka z zespołem Haydamaky. 
dawnymi czasy, życia w związku z dziełem"20, dominują kręgi tematyczne; wystarczy pod tym kątem przejrzeć spisy treści. Innymi słowy rozmowy „z" stają się jednocześnie rozmowami „o"21 z wyraźnym nakierowaniem na współczesność i codzienność. Wśród powtarzających się tematów wyróżnia się płeć kulturowa, w każdej rozmowie problematyzowana, zazwyczaj na zasadzie niechęci do stereotypów i domykania w schematach (np. Stasiuk przekornie pisze o swojej kobiecości, Pilch celebruje męskość, opowiada o kolekcjach szalików i kapeluszy). Cielesność zajmuje jedno z pierwszych miejsc, dawniej było to raczej nie do pomyślenia. Temat chorób, dolegliwości, starzenia się, tycia, używek, diety, gimnastyki itd. dzisiaj nikogo nie dziwi. Znacznie więcej obecnie prywatności, zwierzeń: o emocjonalnych relacjach z rodzicami, o własnych dzieciach, ale także analiz własnego wnętrza, rozważań na temat uczuć i doznań zwłaszcza zmysłowych (szczególnie Stasiuk), na temat wstydu, miłości (Stasiuk, Tulli), ale także spraw ostatecznych.

We wszystkich właściwie bez wyjątku rozmowach daje się zaobserwować zwrot w stronę życia, jego pochwała, swoisty witalizm, często utożsamiany z kontaktem z naturą czy z wolnością podróżnika: Stasiuk: „Po tygodniu jazdy przez step chciałem zdjąć ubranie i wejść na golasa w ten pejzaż. Kucać, zbierać suche gówno, bo tam przecież nie ma drewna, palić ognisko, robić kawę. Ta przestrzeń jest fizycznie odczuwalna. Się wchodzi i idzie. I wiesz. Że nic cię nie ogranicza” (37). Masłowska: „i babrząc się w błocie, nagle poczułam się z powrotem żywa" (178). Problematyzowane jest uczestnictwo w świecie, w relacjach międzyludzkich, choć zazwyczaj w sposób ambiwalentny, przy dosyć wyraźnej niechęci do zbiorowisk, do działań „stadnych”. Zwłaszcza że każdy/każda ogłasza swoją odmienność, deklaruje nieprzystosowanie, bycie w kontrze. Trudno zarazem nie zauważyć, że w nasileniu pojawiają się sprawy bieżące. Co prowadzi do następnej sprawy, otóż w porównaniu z wcześniejszymi rozmowami wyraźnie zaznacza się aspekt interwencyjny, chęć zabrania głosu, w przekonaniu, że - na niektóre przynajmniej tematy - nie można dłużej milczeć. Co staje się obecnie signum temporis. Spośród wielu nasuwających się odpowiedzi na pytanie o ciągłą żywotność rozmów ta potwierdzająca konieczność słyszalności głosu pisarza okazuje się niepozbawiona racji.

\footnotetext{
20 Przypominam: tak - ironicznie - rozpoczął Gombrowicz swoje fikcyjne rozmowy z Dominikiem de Roux.

21 Podobny zabieg widoczny jest już w rozmowach Fiałkowskiego z Lemem.
} 


\section{Abstract}

\section{Anna Łebkowska}

JAGIELLONIAN UNIVERSITY (CRACOW)

Interviews with (Woman) Writers: A New Variety?

Łebkowska explores the returning wave of "interviews with writers" with a focus on woman writers, who had long been neglected in Poland. Among the common features of this new variety she identifies a certain vitalism (often associated with being in touch with nature or with the freedom of a traveller) as well as a turn towards the everyday, the body, emotions and a problematisation of human relationships. Compared with older interviews this new variety is marked by intervention, a desire to speak up, based on the belief that the silence must be broken - at least with regard to certain topics. There are many answers to the question why such interviews continue to thrive, but the one that seems most relevant today centres on the idea that a writer's voice must be heard.

\section{Keywords}

contemporary literature, affect, body, gender, literary genre, interview with a (woman) writer 